\section{Influence of Plant Frequency and Certain Morphological Variations on Diets of Rangeland Grasshoppers}

\author{
D. N. UECKERT1, R. M. HANSEN, AND C. TERWILLIGER, JR. \\ Graduate Research Fellow and Professors of Range Science, Range Science \\ Department, Colorado State University, Fort Collins.
}

\section{Highlight}

The frequency of plant species in the diets of 14 grasshopper species, collected on rangeland lightly grazed by cattle at the Eastern Colorado Range Stacion, was determined by microscopic examination of crop contents. Significant correlations were found between frequency of plant species in the habitat and the frequency of plant species in the diets of all grashopper species except Melanoplus confusus. No correlation was found between the body weight or potential mobility of grasshopper species and the degree to which plant frequency influences their diets. As the number of plant species eaten increased, the influence of the relative availability of plant species on the diets decreased. There was no correlation between either body weight or potential mobility and the number of plant species eaten or the number of plant species/crop.

Grasshoppers, which are generally regarded as the most destructive insect to range vegetation, commonly damage range plants most severely when drought conditions prevail, thus the effects of their feeding are severe (Stoddart and Smith, 1955). Rangeland grasshoppers differ widely in their feeding habits, and the high degree of selectivity in their feeding is well documented. Many theories have been presented in attempts to understand the mechanism of food selection in grasshoppers. Mulkern, Toczek, and Brusven (1964) reported that the degree of selectivity, that is the number of plant species eaten, is inherent in a grasshopper species, but the expression of selectivity is determined by the habitat. Leaves of different plants differ relatively little in nutritional substances needed by insects and substances of no nutritional value, such as glucosides, essential oils, alkaloids, saponins, or tannins, act as olfactory and contact chemical stimuli which are effective at extraordinarily low concentrations (Fraenkel, 1953; Dethier, 1954). Painter (1953) suggested that plant-feeding insects

\footnotetext{
${ }^{1}$ Present address is Assistant Professor, Range and Wildlife Managcment Dcpartment, Texas Tech University, Lubbock, Texas 79409. Received March 5, 1971.
}

are attracted to those plants that are nutritionally satisfactory because the two organisms evolved together, and that any strain that had a behavior pattern that caused it to feed on toxic plants or nutritionally deficient plants would be eliminated.

Size and mobility of insects may affect feeding habits, food selection, and energy flux. Mulkern, Anderson, and Brusven (1962) observed that the variety of food plants ingested by grasshoppers increases with morphologic development of the insect due to smaller crop capacity and less mobility of the younger instars. However, they observed no relationship between the adult size of a species and the number of plant species eaten. Langford (1930) reported that adult female Melanoplus bivittatus consume 2.5 times more forage than males of the same species. Male grasshoppers assimilate larger percentages of inmann, 1965). Larger body sizes in insects result in increased food intake (Reichle, 1968) and increased metabolic rate (Wiegert, 1965).

Various plant species have different effects upon survival, longevity, fecundity, body size and proportions, and rate of development of grasshoppers. Scharff (1954) indicated that seasonal and yearly varigested food than females (Kauf- ations in the general food-plant complex may be important determinants in the build-up or decrease of Melanoplus mexicanus populations. Mulkern et al. (1962) reported that grasshopper species with high population densities in alfalfa fields ingested plant species in almost direct proportion to their abundance. Both the taxonomic composition and the physical structure of the vegetation have been reported to be important environmental factors in determining the distribution of grasshoppers (Cantrall, 1943; Isely, 1944; Isely, 1946; Wolcott, 1937; Anderson, 1964; Kaufmann, 1965).

There is a close correlation of the structure of mandibles and feeding habits in grasshoppers. Kaufmann (1965) indicated that grasshoppers with different feeding habits have differently shaped maxillary lacinia and that mandibles can be classified as the graminivorous-type, the forb-feeding type, and the moss-feeding type.

Comprchensive reviews of the literature concerning the effects of grasshoppers on rangeland and the food habits of grasshoppers have been prepared by Mulkern (1967), Ueckert (1968a), and Mulkern et al. (1969).

Almost every year, millions of dollars are spent on rangeland grasshopper control and forecasting of future population levels. If our ultimate goal is understanding the ecology of rangeland and efficient control of pest species, then exact knowledge of interrelationships, behavior, and life histories is essential. The purpose of this study was to determine the influence of plant frequency, body weight, and potential mobility upon the feeding habits and diets of 14 grasshopper species common on sandhill rangeland in northeastern Colorado.

\section{Methods and Materials}

\section{Study Area}

The study area was a 40.5 ha pasture on the Eastern Colorado Range Station, located $27 \mathrm{~km}$ north of Akron, in Washington County, 
Colorado. The pasture had been lightly grazed by steers ( 4 ha/steer) during the 5 summer months for 13 years prior to this study. The climate of the area is semiarid with an average annual precipitation of about $38 \mathrm{~cm}$, most of which comes as rain during the growing season. The frost-free season usually starts in May and lasts until early October. This study was restricted to the "deep sand" range sites where soil textures are sandy loam and loamy sand, and the topography is dune type with no definite drainage patterns.

The study area is in a BoutelouaCalamovilfa-Stipa-Artemisia association in the mixed-grass prairie in which grasses make up about $80 \%$ of the total dry weight of aboveground vegetation. The major grasses and their contribution to total herbage production include blue grama (Bouteloua gracilis), $42 \%$; prairie sandreed (Calamovilfa longifolia), 18\%; and needleandthread (Stipa comata), 16\%. Other important grasses include sand dropseed (Sporobolus cryptandrus), western wheatgrass (Agropyron smithii), and sand bluestem (Andropogon hallii). Sand sagebrush (Artemisia filifolia) is the only important shrub on the study area. Forbs make up about $6 \%$ of the total dry weight of above-ground plant biomass. Common forbs include western ragweed (Ambrosia psilostachya), scarlet globemallow (Sphaeralcea coccinea), lambsquarters (Chenopodium album), and scurfpea (Psoralea spp.).

The frequency of plant species on the study area was recorded on 1000 quadrats on 1-3 July 1968, by a "nested quadrat" technique (Hyder et al., 1965). The frequency for blue grama was rccorded on a $5 \times 5-\mathrm{cm}$ quadrat and a $40 \times 40-\mathrm{cm}$ quadrat was used for all other species. We assumed that plant frequency in this plant association would not change appreciably during the growing season.

\section{Grasshopper Diets}

About 50 adult specimens of each of the most numerous species of

Table 1. Plant frequency $(\%)$ on $1,00040 \times 40-\mathrm{cm}$ plots on rangeland lightly grazed by cattle at Eastern Colorado Range Station, 1968.

\begin{tabular}{|c|c|c|c|}
\hline Plants & Frequency & Plants & ency \\
\hline Grasses and grasslike plants & \multicolumn{2}{|r|}{ Forbs (continued) } & \\
\hline Agropyron smithii & 17.1 & Euphorbia spp. & 0.2 \\
\hline Andropogon hallii & 3.8 & Evolvulus nuttallianus & 1.6 \\
\hline Aristida longiseta & 0.7 & Gaura coccinea & 0.7 \\
\hline Bouteloua gracilis ${ }^{1}$ & 64.9 & Haplopappus spinulosus & 0.2 \\
\hline Calamovilfa longifolia & 70.3 & Hoffmannseggia jamesii & 0.1 \\
\hline Festuca octoflora & 38.0 & Ipomoea leptophylla & 0.3 \\
\hline Hordeum jubatum & 0.6 & Lepidium densiflorum & 4.2 \\
\hline Sporobolus cryptandrus & 3.9 & Lesquerella ludoviciana & 0.1 \\
\hline Stipa comata & 60.9 & Liatris punctata & 0.4 \\
\hline \multirow[t]{3}{*}{ Carex heliophila } & \multirow[t]{3}{*}{11.1} & Lithospermum incisum & 1.1 \\
\hline & & Lupinus pussilus & 0.1 \\
\hline & & Lygodesmia juncea & 0.1 \\
\hline Forbs & & Opuntia humifusa & 2.0 \\
\hline Ambrosia psilostachya & 32.6 & Penstemon albidus & 0.3 \\
\hline Artemisia filifolia & 10.3 & Phlox spp. & 1.0 \\
\hline Artemisia ludoviciana & 5.4 & Physalis subglabrata & 0.2 \\
\hline Asclepias pumila & 2.7 & Plantago purshii & 0.6 \\
\hline Astragalus spp. & 1.0 & Psoralea lanceolata & 1.7 \\
\hline Chenopodium album & 18.4 & Psoralea tenuiflora & 5.1 \\
\hline Cirsium undulatum & 1.9 & Sphaeralcea coccinea & 5.4 \\
\hline Crolon texensis & 0.1 & Thelesperma megapotamicum & 5.2 \\
\hline Cryptantha sp. & 0.5 & Tradescantia occidentalis & 3.4 \\
\hline Eriogonum annum & 0.9 & Yucca glauca & 0.1 \\
\hline
\end{tabular}

${ }^{1}$ Frequency for Bouteloua gracilis was recorded on a $5 \times 5$-cm plot.

grasshoppers were collected biweekly during the 1968 growing season. Specimens were captured with sweep nets or by hand from the study area. Captured specimens were killed immediately in 95\% ethanol and stored in the alcohol until laboratory work was begun. Several specimens of each species were saved as reference specimens for identification. An ocular estimate of the density of grasshopper populations was made during each collection period.

A microscope slide was prepared from the contents of each individual grasshopper crop, and the composition of diets was estimated by examining the slides under a microscope as described by Ueckert (1968b). Plant tissues on slides were identified by comparison with reference tissue of identified plants. Twenty fields/slide were examined and frequency percentages were calculated for each food item present.

Correlation coefficients were calculated between the percent fre- quency of the plant species on the study area and the percent frequency of the plant species in the diet of each grasshopper species to determine the degree to which diets are influenced by plant frequency. A correlation coefficient was calculated between the diet-plant frequency correlation coefficients for all grasshopper species and the number of plant species eaten to determine the influence of dietary selectivity upon the degree to which diets are influenced by plant frequency.

Femur and tegmen lengths and body weights were determined on 21 to 46 specimens of each sex for 11 grasshopper species. An approximate live weight was obtained on individual specimens by air-drying the alcohol-preserved spccimens for about 2 hours at room temperature and then weighing them. The mobility of each grasshopper species studied was assumed to be proportional to its mean femur and tegmen lengths. Correlation coefficients were calculated between 
means of each of these three measurements and (1) the total number of different plant species eaten by each grasshopper species, and (2) the mean number of plant species/ crop for each grasshopper species, to determine the correlation betwcen grasshopper mobility and body weight and their feeding selectivity and grazing habits.

Correlation coefficients were calculated between the mean body weight, tegmen length, and femur length of each grasshopper species and their diet-plant frequency correlation coefficients to determine if the influence of plant frequency upon the diet of a grasshopper species is a function of its potential mobility or weight.

\section{Results}

Species of plants occurring in $10 \%$ or more of the frequency plots included prairie sandreed, blue grama, needleandthrcad, six-weeks fescue (Festuca octoflora), western ragweed, lambsquarters, western wheatgrass, and sand sagebrush (Table 1).

Grasshopper collections were begun in early May of 1968 and concluded in mid-September of 1968. The crop contents of 2173 grasshoppers, of 14 species, were examined. Epidermal tissue of 43 plant species was identified in crop samples (Table 2). Several species of important forage plants, including western wheatgrass, blue grama, prairie sandreed, needleandthread, and sedge, were major foods of most of the grasshopper species studied (Table 2). The population density of grasshoppers on the study area increased from about $2 / \mathrm{m}^{2}$ in early May to about $20 / \mathrm{m}^{2}$ in mid-June and remained near this level throughout the summer. The number of specimens of each species analyzed does not represent its relative abundance.

Correlation coefficients between the percent frequency of plant species in the diet and the percent frequency of plant species in the habitat were positive and significant $(P$ $=0.01$ ) for all grasshopper species

Table 2. Frequency (\%) of plant species in the diets of 14 grasshopper species common on sandhill rangeland in northeastern Colorado.

\begin{tabular}{|c|c|c|c|c|c|c|c|c|c|c|c|c|c|c|}
\hline \multirow[b]{2}{*}{ Plant species } & \multicolumn{14}{|c|}{ Grasshopper species ${ }^{1}$} \\
\hline & 1 & 2 & 3 & 4 & 5 & 6 & 7 & 8 & 9 & 10 & 11 & 12 & 13 & 14 \\
\hline Agropyron smithii & 12 & 3 & 28 & 21 & 17 & 1 & 4 & 7 & 4 & 6 & 26 & 28 & 1 & 32 \\
\hline Andropogon hallii & $<\mathrm{l}$ & & 4 & & & & 1 & 1 & $<\mathbf{1}$ & 7 & 2 & 5 & & \\
\hline Aristida longiseta & $<1$ & 1 & & $<1$ & & $<1$ & $<1$ & & & & & & & \\
\hline Bouteloua gracilis & 42 & 74 & 16 & 9 & 46 & 37 & 8 & 1 & 8 & 37 & 1 & 22 & 84 & 19 \\
\hline Bromus tectorum & & & $<1$ & & & & & & & & & & & \\
\hline Buchloe dactyloides & & & & & & & & & & & & 4 & & \\
\hline Calamovilfa longifolia & 13 & 2 & 4 & 3 & 7 & 44 & 4 & 3 & 6 & 33 & 9 & 5 & & \\
\hline Cenchrus pauciflorus & & & & & & & $<1$ & & & & & & & \\
\hline Festuca octoflora & 3 & & 17 & & & 8 & $<1$ & $<1$ & $<\mathrm{l}$ & & 30 & 1 & $<\mathbf{l}$ & 17 \\
\hline Koeleria cristata & $<1$ & & & & & & $<1$ & & & & & & & \\
\hline Paspalum stramineum & & & & & & & & & & & & & & \\
\hline Sporobolus cryptandrus & 1 & & & $<1$ & & 1 & 7 & & 4 & & 1 & 9 & 1 & $<1$ \\
\hline Stipa comata & 27 & 21 & 28 & 62 & 28 & 12 & 5 & 2 & 4 & 18 & 18 & 11 & 15 & 29 \\
\hline Carex heliophila & 4 & & 4 & 11 & 1 & 2 & I & & 3 & & 17 & 4 & & \\
\hline Juncus balticus & $<1$ & & & $<1$ & & $<1$ & $<\mathbf{l}$ & & & & & 1 & & \\
\hline Amaranthus retroflexus & & & $<1$ & & & & & 1 & 1 & & 3 & 9 & & \\
\hline Ambrosia psilostachya & & & & & & & 16 & 3 & 11 & & $<1$ & 1 & & \\
\hline Argemone intermedia & & & & & & & 1 & & 2 & & & & & \\
\hline Artemisia filifolia & & & & & & & 4 & 14 & 5 & & & & & \\
\hline Asclepias pumila & & & & & & & & & 3 & & & & & \\
\hline Astragalus spp. & & & & & & & 5 & 1 & 3 & & & & & \\
\hline Chenopodium album & & & & & & & 1 & 1 & $<1$ & & $<1$ & & & $<1$ \\
\hline Cirsium undulatum & & & & & & & 3 & 7 & 7 & & & & & \\
\hline Croton texensis & & & & & & & 4 & & 4 & & & & & \\
\hline Eriogonum annum & & & & & & & & 3 & & & & & & \\
\hline Euphorbia spp. & & & & & & & & & 1 & & & & & \\
\hline Evolvulus nuttallianus & & & & & & & 1 & 1 & 10 & & & $<1$ & & \\
\hline Ipomoea leptophylla & & & & & & & 3 & & $<1$ & & & $<1$ & & \\
\hline Kochia scoparia & & & & & & & & $<1$ & & & & & & \\
\hline Lepidium densiflorum & & & & & & & & 4 & & & & & & \\
\hline Lesquerella ludoviciana & & & & & & & 1 & 1 & $<1$ & & & & & \\
\hline Liatris punctata & & & & & & & $<1$ & & & & & & & \\
\hline Lithospermum incisum & & & & & & & 2 & & & & & & & \\
\hline Lupinus pussilus & & & & & & & $<1$ & & 1 & & & 1 & & \\
\hline Medicago sativa & & & & & & & 2 & & 2 & & & & & \\
\hline Melilotus alba & & & & & & & 2 & & & & & & & \\
\hline Penstemon albidus & & & & & & & & 3 & 1 & & & & & \\
\hline Psoralea lanceolata & & & & & & & 2 & & & & & & & \\
\hline Psoralea tenuflora & & & & & & & 2 & 3 & 7 & & & & & \\
\hline Solanum rostratum & & & & & & & & & 1 & & & & & \\
\hline Sphaeralcea coccinea & & & & & & & 1 & 1 & 5 & & & $<1$ & & \\
\hline Tradescantia occidentalis & & & & & & & 1 & 37 & 2 & & & 4 & & \\
\hline Tribulus terrestris & & & & & & & $<1$ & & & & & & & \\
\hline
\end{tabular}

${ }_{1}$ Grasshopper species by number are: 1-Ageneotettix deorum, 2-Amphitornus coloradus, 3-Arphia conspersa, 4-Arphia pseudonietana, 5-Cordillacris occipitalis, 6Eritettix simplex, 7-Melanoplus angustipennis, 8-Melanoplus confusus, 9-Melanoplus foedus, 10-Mermiria maculipennis, 11-Pardalophora apiculata, 12-Spharagemon collare, 13-Trachyrhachys kiowa, and 14-Xanthippus corallipes.

except Melanoplus confusus (Table 3). Plant frequency in the habitat accounted for as much as $74 \%\left(\mathrm{r}^{2}=\right.$ 0.74 ) of the variability of plant frequency in the diets of Eritettix simplex and Mermiria maculipennis, and for as little as $21 \%\left(\mathrm{r}^{2}=0.21\right)$ of the variability of plant frequency in the diet of Melanoplus foedus.

Females were from 1.2 to 3.6 times heavier and had femora and tegmina from 1.0 to 1.3 times longer than males of their respective species. Mean grasshopper weights varied from $184 \mathrm{mg}$ for Eritettix simplex to $1,120 \mathrm{mg}$ for Pardalophora apiculata while femur and tegmen lengths varied from 1.12 $\mathrm{cm}$ and $1.27 \mathrm{~cm}$ respectively for Ageneotettix deorum to $1.93 \mathrm{~cm}$ and $3.43 \mathrm{~cm}$ respectively for $P$. apiculata (Table 4). 
Table 3. Correlation of the frequency (\%) of plant species in the diets of 14 species of grasshoppers with the frequency $(\%)$ of plant species in their habitat at Eastern Colorado Range Station.

\begin{tabular}{lr}
\hline \hline \multicolumn{1}{c}{ Species } & \multicolumn{1}{c}{$\mathrm{r}^{1}$} \\
\hline Eritettix simplex & +0.86 \\
Mermiria maculipennis & +0.86 \\
Ageneotettix deorum & +0.81 \\
Cordillacris occipitalis & +0.74 \\
Arphia conspersa & +0.67 \\
Xanthippus corallipes & +0.65 \\
Amphitornus coloradus & +0.62 \\
Trachyrhachys kiowa & +0.57 \\
Arphia pseudonietana & +0.56 \\
Pardalophora apiculata & +0.52 \\
Melanoplus angustipennis & +0.52 \\
Spharagemon collare & +0.51 \\
Melanoplus foedus & +0.45 \\
Melanoplus confusus & +0.042 \\
\hline 1.ll correlation coefficients are significant \\
at the 1\% level of significance except for \\
Melanoplus confusus. \\
2 Not significant at the 5\% level of signifi- \\
\multicolumn{2}{c}{ cance. }
\end{tabular}

The number of plant species eaten varied from 6 to 38 in the grasshopper species studied. Amphitornus coloradus, Cordillacris occipitalis, Mermiria maculipennis, and Trachyrhachys kiowa each fed on six plant species while Melanoplus angustipennis fed on 38 plant species (Table 4). The mean number of plant species/crop varied from 1.1 in M. maculipennis to 3.0 in $M$. angustipennis.

Correlation coefficients of femur lengths, tegmen lengths, and body weights of 11 grasshopper species and the number of plant species eaten were not significant $(P=$ 0.05). Correlation coefficients of the same three body measurements of the 11 species and the mean number of plant species/crop were not significant $(\mathbf{P}=0.05)$. Correlation coefficients of femur lengths, tegmen lengths, and body weights of the 11 species and their diet-plant frequency correlation coefficients were not significant $(P=0.05)$.

There was a negative correlation $(\mathrm{r}=-0.55)$ between diet-plant frequency correlation coefficients and the number of plant species caten
Table 4. Number of plant species eaten, mean number of plant species/crop, mean femur and tegmen lengths $(\mathrm{cm})$, approximate mean live wcights $(\mathrm{mg})$, and number of crops examined from grasshoppers collected at Eastern Colorado Range Station, 1968.

\begin{tabular}{lrcccrr}
\hline \hline \multicolumn{1}{c}{$\begin{array}{c}\text { Glant } \\
\text { Grasshopper species }\end{array}$} & $\begin{array}{c}\text { Mean no. } \\
\text { species } \\
\text { eaten }\end{array}$ & $\begin{array}{c}\text { plant } \\
\text { species/crop }\end{array}$ & $\begin{array}{r}\text { Mean } \\
\text { femur }\end{array}$ & $\begin{array}{c}\text { Mean } \\
\text { tegmen }\end{array}$ & $\begin{array}{c}\text { Mean } \\
\text { weight }\end{array}$ & $\begin{array}{c}\text { Total } \\
\text { co. } \\
\text { crops }\end{array}$ \\
\hline Ageneotettix deorum & 12 & 1.9 & 1.12 & 1.27 & 187 & 250 \\
Amphitornus coloradus & 6 & 1.2 & 1.28 & 1.70 & 212 & 97 \\
Arphia conspersa & 11 & 1.6 & 1.35 & 2.46 & 514 & 191 \\
Arphia pseudonietana & 9 & 1.5 & 1.58 & 2.77 & 678 & 151 \\
Cordillacris occipitalis & 6 & 1.2 & & & & 90 \\
Eritettix simplex & 10 & 1.5 & 1.14 & 1.39 & 184 & 146 \\
Melanoplus angustipennis & 38 & 3.0 & 1.19 & 1.64 & 210 & 227 \\
Melanoplus confusus & 24 & 1.9 & & & & 106 \\
Melanoplus foedus & 34 & 2.7 & 1.48 & 2.16 & 480 & 151 \\
Mermiria maculipennis & 6 & 1.1 & & & & 84 \\
Pardalophora apiculata & 13 & 2.1 & 1.93 & 3.43 & 1420 & 110 \\
Spharagem.nn collare & 19 & 2.1 & 1.47 & 2.53 & 525 & 144 \\
Trachyrhachys kiowa & 6 & 1.2 & 1.19 & 1.95 & 223 & 200 \\
Xanthippus corallipes & 14 & 1.9 & 1.82 & 3.33 & 1378 & 226 \\
\hline
\end{tabular}

${ }^{1}$ Average of male and female means.

by the grasshopper species studied $(\mathrm{P}=0.05)$.

\section{Discussion}

Although all herbivores have food preferences, it is only logical to expect that plant frequency in their habitat exerts some degree of influence upon their food habits. The frequency of a species of plant in the habitat determines how often a herbivore will encounter it as it moves about. Similarly, the percent of the total biomass of live, aboveground vegetation that a plant species comprises determines its relative availability as a potential food for herbivores.

A non-selective feeder could be expected to eat foods exactly in proportion to the frequency with which they were encountered, and consequently, $100 \%$ of the variability in its diet would be associated with plant frequency. In this study there was statistically significant correlation between the frequency of plants in the habitat and the frequency of plants in the diets of all grasshopper species except $M$. confusus. As much as $74 \%$ of the variability in the diets of $E$. simplex and $M$. maculipennis may be associated with plant frequency in their habitat. Although some of the lower correlation coefficients may not be ecologically important, this study provides evidence that the diets of grasshoppers are influenced by the plant composition in the habitat, even though strong feeding preferences are expressed.

The influence of plant frequency upon feeding habits varies among grasshopper species. There was no correlation between the body weight or potential mobility of grasshopper species and the degree to which plant frequency influences diets. The food preferences of a grasshopper species are apparently genetically inherited traits and are not dictated by the grasshopper's ability to search for foods. However, a negative correlation was found between the number of plant species eaten by the grasshopper species studied and the influence of plant frequency upon their diets. As feeding selectivity decreased (or the number of plant species eaten increased) the influence of the relative availability of plant species on the diet decreased, thus diets of species which feed on few different plant species (stenophagous) are generally influenced more by plant frequency than are diets of species which feed on many different plant species (euryphagous). 
The number of plant species in the diet of a herbivore is an index of selectivity; stenophagous herbivores are more selective, whereas euryphagous species are more general feeders. It would seem that euryphagous species should be able to adapt to more niches than stcnophagous species, and thus be favored by evolutionary selection. However, specialization (in diet or otherwise) is generally considered to be a deepening rut in evolution (National Academy of Sciences, 1968).

There was no correlation between body weight or potential mobility of the grasshopper species studied and the number of plant species eaten or the number of plant species in their crops while grazing under natural conditions. Large grasshoppers are not more highly selective nor less selective than smaller, less mobile species. Larger species do not move from plant to plant while feeding any more than smaller and less mobile species.

\section{Litcrature Cited}

Anderson, N. L. 1964. Some relationships between grasshoppers and vegetation. Entomol. Soc. Amer., Ann. 57:736-742.

Cantrall, I. J. 1943. The ecology of the Orthoptera and Dermaptera of the George Reserve, Michigan. Mus. Zool. Univ. Michigan, Misc. Pub. 54:1-182.

National Academy of Sciences, Committee on Plant and Animal Pests, Subcommittee on Weeds. 1968. The biological control of weeds, p. 86-
119. In Principles of Plant and animal pest control, Vol. 2 weed control. Pub. 1597. Nat. Acad. of Sci., Washington, D. C. $471 \mathrm{p}$.

DetHIER, V. G. 1954. Evolution of feeding preferences in phytophagous insects. Evolution 8:33-54.

FraENKEL, G. 1953. The nutritional value of green plants for insects. Ninth Int. Congr. Entomol., Trans. 2:90-100.

Hyder, D. N., R. E. Bement, E. E. ReMmenGa, AND G. TeRWILliger, JR. 1965. Frequency sampling of blue grama range. J. Range Manage. 18: 90-94.

IsELy, F. B. 1944. Correlation between mandibular morphology and food specificity in grasshoppers. Entomol. Soc. Amer., Ann. 37:47-67.

Isely, F. B. 1946. Differential feeding in relation to local distribution of grasshoppers. Ecology 27:128-138.

Kaufmann, T. 1965. Biological studies on some Bavarian Acridoidea (Orthoptera), with special reference to their feeding habits. Entomol. Soc. Amer., Ann. 58:791-801.

LANGFORD, G. S. 1930. Some factors relating to the feeding habits of grasshoppers with special reference to Melanoplus bivattatus. Colorado Agr. Exp. Sta. Bull. 354. 53 p.

Mulkern, G. B. 1967. Food selection by grasshoppers. Ann. Rev. Entomol. 12:59-78.

Mulkern, G. B., J. F. Anderson, and M. A. Brusven. 1962. Biology and ecology of North Dakota grasshoppers. I. Food habits and preferences of grasshoppers associated with alfalfa fields. North Dakota Agr. Exp. Sta. Res. Rep. No. 7. 25 p.

Mulkern, G. B., K. P. Pruess, H. Knutson, A. F. Hagen, J. B. Campbell, and J. D. Lambley. 1969. Food habits and preferences of grassland grasshoppers of the north central great plains. North Dakota Agr. Exp. Sta. Bull. No. 481. 32 p.

Mulkekn, G. B., D. R. ToczeK, AND M. A. Brusven. 1964. Biology and ecology of North Dakota grasshoppers. II. Food habits and preferences of grasshoppers associated with the sand hills prairie. North Dakota Agr. Exp. Sta. Res. Rep. No. 11. $59 \mathrm{p}$.

Painter, R. H. 1953. The role of nutritional factors in host plant selection. Ninth Int. Congr. Entomol., Trans. 2:101-105.

REICHLE, D. E. 1968. Relation of body size to food intake, oxygen consumption, and trace element metabolism in forest floor arthropods. Ecology 49:538-542.

ScharfF, D. K. 1954. The role of food plants and weather in the ecology of Melanoplus mexicanus mexicanus (Sauss.). J. Econ. Entomol. 47:485489.

Stoddart, L. A., ANd A. D. Smith. 1955. Range management. McGraw-Hill Book Co. Inc., New York. 433 p.

UECKERT, D. N. 1968a. Diets of some grasshoppers common on mountain herbland in northern Colorado. M.S. Thesis. Colorado State Univ. Fort Collins, Colorado. 43 p.

UECKERT, D. N. 1968b. Seasonal dry weight composition in grasshopper diets on Colorado herbland. Entomol. Soc. Amer., Ann. 61:1539-1544.

Wiegert, R. G. 1965. Energy dynamics of the grasshopper populations in old field and alfalfa field ecosystems. Oikos 16:161-176.

Wolcott, G. N. 1937. An animal census of two pastures and a meadow in northern New York. Ecol. Monogr. 7:1-90.

\section{Annual Meeting}

\section{February 5-11 Washington, D. C.}

Information concerning the program, special events, and accommodations were presented in the November 1971 Journal of Range Management and the December 1971 Rangeman's News.

Preregistration is open until January 31. Please contact the Executive Secretary, 2120 South Birch Street, Denver, Colorado 80222 for additional information. 